\title{
Students' Word Associations with Different Terms Related to the Wadden Sea: Does the Place of Residence (Coast or Inland) Have an Influence?
}

\author{
Till Schmäing *(D) and Norbert Grotjohann
}

Citation: Schmäing, T.; Grotjohann, N. Students' Word Associations with Different Terms Related to the Wadden Sea: Does the Place of Residence (Coast or Inland) Have an Influence? Educ. Sci. 2021, 11, 284. https://doi.org/10.3390/

educsci11060284

Academic Editor: Eila Jeronen

Received: 31 March 2021

Accepted: 6 June 2021

Published: 8 June 2021

Publisher's Note: MDPI stays neutral with regard to jurisdictional claims in published maps and institutional affiliations.

Copyright: (C) 2021 by the authors. Licensee MDPI, Basel, Switzerland. This article is an open access article distributed under the terms and conditions of the Creative Commons Attribution (CC BY) license (https:// creativecommons.org/licenses/by/ $4.0 /)$.
Faculty of Biology, Didactics of Biology (Botany/Cell Biology), University of Bielefeld, 33615 Bielefeld, Germany; norbert.grotjohann@uni-bielefeld.de

* Correspondence: till.schmaeing@uni-bielefeld.de

\begin{abstract}
This paper presents students' word associations with terms regarding the Wadden Sea. A continuous free word-association method was used in which the students from secondary schools ( $n=3119$, average age: 13.54 years) reported their associations with the stimulus words Wadden Sea, mudflat hiking tour, and tides in written form. Data were collected from students living close to the Wadden Sea and from students living inland. We performed a quantitative content analysis including the corresponding formation of categories. In addition, students' school, out-of-school with the class, and private experiences the Wadden Sea ecosystem were recorded. The study shows that not only subject-related concepts should be considered at different levels, but non-subject-related aspects as well. The associations of the inland and non-inland students are statistically significantly different. The Wadden Sea and its biome were found to be completely unknown to some students. Students' school, out-of-school with the class, and private experiences of the wetlands are also very mixed, regarding their Wadden Sea visitation frequency, and surprisingly cannot be directly derived from their place of residence. This research makes an important contribution towards the design of future biology didactic studies on the Wadden Sea.
\end{abstract}

Keywords: biology education; didactics of biology; word associations; quantitative content analysis; Wadden Sea; mudflat hiking tour; tides

\section{Introduction}

The Wadden Sea of northeastern Europe extends over a distance of about $450 \mathrm{~km}$ from Skallingen in Denmark, across the entire German North Sea coast, to Den Helder in the Netherlands [1], making it the largest contiguous mudflat area in the world. Although living in this ecosystem is extremely demanding due to the tides, the Wadden Sea is the habitat of over 10,000 different species of animals, plants, and fungi [2]. It also serves as an irreplaceable food source for 10 to 12 million birds during molting, breeding, and wintering or as a stopover during bird migration [3]. Therefore, the Wadden Sea is of particular relevance for global biodiversity. To protect this unique habitat, a trilateral cooperation between Denmark, Germany, and the Netherlands has been in place since 1978 [4]. The Wadden Sea is protected in all three countries on the national level within nature reserves. The national park Schleswig-Holsteinisches Wattenmeer, which was established in 1985, was the first national park for the protection of the Wadden Sea in Germany [5]. Internationally, Germany's tidal flats, as well as those of the Netherlands in 2009 [6], and Denmark in 2014 [7], were designated as UNESCO World Heritage Sites.

Research on the Wadden Sea ecosystem has been conducted in numerous areas in diverse biological disciplines (e.g., zoology [8], botany [9], and genetics [10]). However, these are subject-specific studies. Biology didactic projects, on the other hand, are rare. So far, there has been one study on the influence of an out-of-school intervention by an educational institution at the Wadden Sea on students' systems of thinking [11]. Evaluations of the educational offerings of selected national park institutions [12-14] have also 
been conducted. The Wadden Sea as a learning site was not explicitly considered. In other biology didactic studies including references to the Wadden Sea, the same picture emerges: in the Wadden Sea Learning Laboratory, the focus is on providing practice- and competence-oriented training for biology teachers [15-17], as well as on developing educational offerings for national park education centers [18]. Furthermore, content on the Wadden Sea, among other topics, has served as a standard reference for assessing subject knowledge among teachers $[19,20]$ or as a reference for comparing the performance of teachers with the performance of students [21]. In another study, related content was used to examine the systems literacy of prospective biology teachers [22]. Another perspective of biological education involves research on citizen science and volunteering. In this regard, the Wadden Sea region in Denmark has great potential [23]. Volunteering is also of great importance in German national parks [24]. In the didactics of other subjects, the Wadden Sea as a learning site has not yet become a center of focus. In physics, some studies have focused on developing educational offerings for out-of-school learning locations on the topic of the North Sea $[25,26]$. In geography, a virtual excursion on the Hallig Hooge was developed [27,28], and in art, the art mediation of the Wadden Sea has been implemented on a subject-specific level $[29,30]$. The Wadden Sea as a place of learning has only been thematized in the context of intercultural communication [31], but this is in no way directed at biology didactic content.

This study is part of a larger project that focuses on the Wadden Sea, both as a place of learning, and as an object of instruction from an empirical-research-based biology didactic point of view, and investigates the Wadden Sea from different perspectives [32,33]. Environmental and climate protection is growing in importance among the general population. In a study from $1998,31 \%$ of those surveyed rated environmental and climate protection as very important; in 2019, this value had risen to $68 \%$ [34]. A meta-study indicated that the majority of over 32,000 respondents considered the marine environment to be threatened by human activities [35]. The significance of nature rose among young people during the COVID-19 pandemic [36]. In relation to the Wadden Sea, there are multiple reasons for this increase in the desire to conserve nature. For example, the overarching benefit of the ecosystem, personal experiences, as well as the desire to preserve it from exploitation or destruction from various influences, can be motivations for protecting the Wadden Sea wetlands [37]. The present study identifies students' associations with different terms from the content area of the Wadden Sea, as well as collating their various school, out-of-school with the class, and private experiences of the Wadden Sea. These results are central to the design and implementation of further studies. Due to the research goal of implementing biology didactic studies that have a concrete focus on the Wadden Sea as a place of learning, it is necessary for this study to establish some initial insights regarding this field of research.

\section{Methods}

Due to the lack of biology didactic studies on the Wadden Sea, developing an appropriate methodology for this research field is necessary. One possibility is to capture the learner's perspective. This approach offers the opportunity to enter the field in question, while also allowing future research goals to be identified based on the results obtained.

The range of methods that can generally be used to achieve this overarching goal is extensive. In biology didactics, guided interviews can be conducted to capture learners perspectives [38], documents such as concept maps can be analyzed [39], questionnaires can be used [40], or field observations can be made [41], among others. The aim of the present study is to open the field of biology didactic studies on the Wadden Sea, which has hardly been considered in research so far. To do so, a compromise must be found between the in-depth nature of the anticipated data (the qualitative aspect) and the measurable scope of the data (the quantitative aspect). The research goals necessitate a generally open approach, along with the possibility of quantifying the data. In order to take both aspects into account, a word association method was chosen as the data collection methodology. 


\subsection{Word Association Method}

Associations-especially in psychology—have long been the subject of scientific work, not only in terms of methodological use but also in general [42-44]. Initial theoretical conclusions about associations can already be seen in the writings of Aristotle [45]. Due to the thematic focus of this paper, we will refrain from elaborating on the various definitional approaches from psychology.

Ultimately, what all word association methods have in common is that subjects are asked to report their associations with a given stimulus word. The following discussion presents the four basic methodological implementation possibilities of association experiments, according to Woodworth and Schlosberg [44]. The authors differentiate associations in terms of two dimensions: between free and controlled, and between discrete and continuous. In the discrete-free approach, respondents are asked to name only a single association term for a stimulus word. In the case of a discrete-controlled association, certain conditions are attached to this association word (e.g., regarding the topic). In the case of a continuous-free association, there are no conditions and likewise no limit to the number of association words. Continuous-controlled association, on the other hand, requires specific given conditions but also has no limit on associated words. In this regard, Beatty et al. [46] argue that even in a free association, there are indirect content constraints on the choice of associations as a result of the given stimulus, and therefore refer to this procedure as "quasi-free."

Word association methods have been widely used in biology didactics for several decades [47] and have been described as a relevant method for capturing learners' cognitive structures [48]. Therefore, these methods are well established in the field of didactic research and are used in a variety of research areas with different concrete methodological implementations. For example, there have been studies of students' word associations in different thematic areas, such as on the concept of energy [49,50], that of growth [51], and bioethical issues [52], or of measuring the impact of pedagogical interventions in out-ofschool learning settings $[53,54]$. Similarly, studies have used word association methods to explore the conceptions of prospective biology teachers [55-59] as well as of undergraduate biology students [60]. In addition, there are studies that have looked at, among other things, the word associations of trained teachers [61]. Another possible use of the described methodology is not so much for empirical research but rather for concretely planning lessons [62]. An evaluation of instructional plans is also possible with word association methods [63].

\subsection{Implementation in the Study}

As the above illustrates, there are many possibilities for conducting word association experiments. In the following, we describe, explain, and justify the concrete methodology implemented in this study.

\subsubsection{General Procedure}

To ensure the desired openness of the research methodological procedure, we employed a free form of association. Students ( $n=3119$, average age: 13.54 years) were asked to provide their associations with the stimulus words without any limiting specifications. Thus, any significant methodological influence limiting content is unlikely. Furthermore, we chose to conduct a survey to collect continuous associations. Here, too, the central deciding factor was ensuring the greatest possible openness. Limiting the students' responses to a single association per stimulus word would have run the risk of highly limiting the content. In that case, it would hardly have been possible to broadly index the word associations that arose in response to the stimulus words. Following the definition of Woodworth and Schlosberg [44], the methodological procedure can therefore be described as a continuous-free association methodology. 


\subsubsection{Determination of the Stimulus Words}

The selection of suitable stimulus words is of particular relevance in word association methods [64]. One method that can be used in this process is analyzing suitable documents or interviews with experts [65]. In the present case, in addition to analyzing specialized texts in depth, a special emphasis was placed on consulting with experts from the fields of biology, biology didactics, and environmental education. Among them were people with many years of theoretical and practical scientific experience in the subject area, and in the Wadden Sea as a place of learning. In the literature, there is no uniform information on the appropriate number of stimulus words but, rather, the recognition of a large variation in number. Since the objectives of the present study demand a sample size as large as possible, collecting the data in a time-efficient way is a central consideration. In the first step, all nine experts from the above-mentioned fields considered the stimulus words and their number on their own. This was followed by several discussion meetings in which the respective proposals were intensively debated. In the end, the common goal was to identify associations on different levels and, at the same time, to ensure a high degree of openness. Based on feedback from in-service teachers that time efficiency was important due to a general lack of available class time, we chose to utilize no more than three stimulus words in our study to limit the amount of time needed to complete the survey. In consultation with the nine experts, we selected three stimulus words from the literature. These are shown in Table 1, together with the reasons for their selection.

Table 1. Discussion of stimulus word selection.

\begin{tabular}{|c|c|}
\hline Stimulus Word & Selection Reasons \\
\hline mudflat hiking tour & $\begin{array}{l}\text { In this way, a maximum degree of openness is guaranteed. The } \\
\text { students are completely free to choose on which levels (e.g., } \\
\text { cognitive or emotional) they would like to consider their } \\
\text { associations. In addition, the topic is introduced in an unbiased } \\
\text { way. Thus, associations can be evoked that are very general. } \\
\text { There is also the possibility for specific associations to arise. No } \\
\text { restrictions are given. } \\
\text { This stimulus word focuses on the out-of-school and/or private } \\
\text { sphere. In this way, associations should be elicited that have a } \\
\text { connection to possible experiences of the Wadden Sea, which } \\
\text { can remind the students of any personal experiences that they } \\
\text { may have had. This form of concretization became necessary } \\
\text { primarily because of the didactic focus of the study. } \\
\text { This stimulus word was chosen with the aim of directly } \\
\text { targeting the content level. In the process, the students were } \\
\text { anticipated to engage in a technical discussion of the term, } \\
\text { despite the high degree of openness. Therefore, the word } \\
\text { associations are not too restricted. At the same time, it was } \\
\text { possible to exclude the possibility of this term being associated } \\
\text { with a limitation due to excessive specificity. }\end{array}$ \\
\hline
\end{tabular}

In summary, it was anticipated that the students would be able to name associations with the Wadden Sea on different levels, all within a methodological framework that maintained the necessary high degree of openness.

\subsubsection{Analysis Method}

The selection of evaluation options for word association methods is as diverse as the methods themselves. Ultimately, the analysis method depends on the specific implementation of the experiment. Corresponding studies can be conducted both orally and in writing. Due to practicality and in consideration of the general objectives, a written variant (paper-pencil survey) was chosen. Since the word associations are considered on a purely content-related level, the association time (i.e., the time between the announcement of the 
stimulus word and the naming of the respective association) was not measured, thereby excluding the possibility of evaluations considering a temporal dimension (as in [46]).

In the context of analysis, both the level of an individual and the level of a (selected) group can be considered. One way of presenting results on an individual level is, for example, association chains [51]. This is not practicable for large samples, so we decided against such a form of evaluation. The analysis of the present data was performed with a quantitative content analysis. According to Bortz and Döring [66], a category system can be formed from the data material within a quantitative content analysis (inductive procedure). This in turn serves as the basis for a frequency analysis, which, according to Mayring [67], can also be regarded as a basic form of interpreting qualitative data. Ultimately, the goal was not to form an overarching, highly generalized category system, as is often practiced in studies with comparably large sample numbers (e.g., [68]). The focus of the analysis was to look at associations on as literal a level as possible. Therefore, a detailed system of categories was formed from the data, which closely captured the associations as literally as possible. In addition, this analysis method takes particular account of the "primary response", the association that was named most frequently in response to the respective stimulus word. The measurement of this corresponds to one of the most frequently used analysis methods of word associations [69].

In the analysis, all associations were considered, and no preselection was made. Therefore, associations that have no direct technical connection to the stimulus words are also included in the results. In other research in biology didactics, it was shown that such indirect associations are not unusual, even when the test persons participate seriously and therefore should be considered [70]. Especially considering the lack of data in this field of research, evaluating all the associations is essential to ensure complete impartiality.

\subsubsection{Sample}

In the present study, a total of 3119 students were surveyed, of which 1675 (50.57\% male, average age: 13.40 years) live in the Wadden Sea area (coast sample) and 1444 (50.48\% male, average age: 13.59 years) in North Rhine-Westphalia (inland sample). The students from the inland live about $350 \mathrm{~km}$ from the sea. These students provided a total of 23,168 word associations for the three stimulus words. The selection of participants was done according to recommendations from the literature for qualitative research [71]. The focus was on gaining knowledge in relation to the specific questions [72], so that criteria for the sample were specified [73]. These included the prerequisites that the surveyed students were taught at a secondary school and lived either on the coast or in North RhineWestphalia. In order to ensure comparability between the groups, a comparable size of both subsamples and a similar average age were defined as further prerequisites. In order to exclude a possible bias of the data, the students' experiences of the Wadden Sea were additionally surveyed.

\subsubsection{Statistics}

A $\chi^{2}$-test was performed to statistically validate the results of the comparison between the two groups under consideration. This can be used to test two nominally scaled variables for a correlation. In doing so, the theoretically expected distribution of frequencies is compared with the actual determined results [74]. Such a test procedure was implemented for each stimulus word. Since the expected cell frequency was less than five in some cases, a Monte Carlo simulation was performed in each case. Based on all three calculations, a significant difference in the frequency of associations in the two groups was found. Cramér's V was calculated to represent the effect size [75]. In the results section, both the $\chi^{2}$ - values and the effect sizes are given for the individual stimulus words. 
To ensure the objectivity of the analysis, interrater reliability was tested. Cohen's kappa is also evaluated as a suitable measure of interrater reliability in science didactics [76]. Following other studies in science didactics [77] and general scientific methodological recommendations [78], $10 \%$ of the association sheets were independently analyzed by two individuals. Since, when depending on the category system, a relatively large number of chance matches can be assumed, the maximum $\mathrm{k}$-value to be achieved is often significantly lower than 1 [78]. Different statements can be found in the literature regarding the interpretation of Cohen's kappa. According to Greve et al. [79], a k-value $\geq 0.75$ is to be considered good to excellent; Altman [80] judges a $k$-value of 0.61 as already good. The $\mathrm{K}$-value determined in this analysis was 0.963 , and can thus be considered excellent.

\section{Research Questions}

The central question of the present work is:

1. What word associations do students have with the terms "Wadden Sea", "mudflat hiking tour", and "tides"?

The data were collected from students in two regions of Germany: students living in the immediate vicinity of the Wadden Sea and inland students from the federal state of North Rhine-Westphalia were surveyed. Taking this into account, the question above can be supplemented with another question:

2. Are there any differences between the associations of coastal students living near the Wadden Sea and those of inland students from North Rhine-Westphalia?

Additional data on the students' experiences of the Wadden Sea were collected. The data were measured quantitatively and included a school dimension (lessons), an outof-school dimension (excursions with the school class), and a private dimension (leisure time/holidays). These data are relevant for establishing an approximation of the research field and can serve as starting points for explanations of the associations. Therefore, the following questions can be formulated:

3a. What experiences (school, out-of-school with the class, and private) of the Wadden Sea do students who live on the Wadden Sea have?

$3 \mathrm{~b}$. What experiences (school, out-of-school with the class, and private) of the Wadden Sea do inland students from North Rhine-Westphalia have?

\section{Results}

The following section presents the individual results of the quantitative content analysis of the word associations, as well as the different experiences of the students regarding the Wadden Sea.

\subsection{Quantitative Content Analysis}

For each of the three stimulus words, a tabular overview with the rankings of the most frequent associations is presented below. The individual rankings illustrate both the absolute frequency of an association being mentioned and the relative proportion of the total number of associations per stimulus word. Likewise, the total number of associations as well as the average number of associations per individual student is given.

Tables 2 and 3 show the results for the stimulus word "Wadden Sea". The $\chi^{2}$-test proved that there is a significant correlation between the students' place of residence and the associations provided $\left(\chi^{2}(159)=1990.953, p<0.001\right)$. Cramér's V is 0.451 , so there is a moderate effect [81]. 
Table 2. Stimulus word: Wadden Sea; sample: coast; associations: $n=5793$; associations/individual: 3.46 .

\begin{tabular}{cccc}
\hline Item & Association & $\mathbf{n}$ & $\mathbf{\%}$ \\
\hline 1 & Mud/Sludge & 547 & 9.44 \\
2 & Lugworm & 450 & 7.77 \\
3 & Water & 409 & 7.06 \\
4 & Animals & 349 & 6.02 \\
5 & Mudflat & 309 & 5.33 \\
6 & Crabs & 297 & 5.13 \\
7 & Mussels & 278 & 4.80 \\
8 & Ebb & 275 & 4.75 \\
9 & Flow & 204 & 3.53 \\
10 & Silt & 202 & 3.49 \\
11 & Sea & 192 & 3.31 \\
12 & Birds & 130 & 2.24 \\
13 & Sand & 128 & 2.21 \\
14 & North Sea & 123 & 2.12 \\
15 & Walking on the & 110 & 1.90 \\
\hline
\end{tabular}

Table 3. Stimulus word: Wadden Sea; sample: inland; associations: $n=3981$; associations/individual: 2.76 .

\begin{tabular}{cccc}
\hline Item & Association & $\mathbf{n}$ & \% \\
\hline 1 & Mud/Sludge & 381 & 9.57 \\
2 & Ebb & 377 & 9.47 \\
3 & Flow & 299 & 7.52 \\
4 & Sea & 257 & 6.46 \\
5 & Lugworm & 226 & 5.68 \\
6 & Ships & 224 & 5.63 \\
6 & North Sea & 224 & 5.63 \\
8 & Term is unknown & 154 & 3.87 \\
9 & Water & 153 & 3.84 \\
10 & Wadding (cotton filling) & 142 & 3.57 \\
11 & Sand & 134 & 3.37 \\
12 & Waterless seabed & 118 & 2.97 \\
13 & Baltic Sea & 89 & 2.24 \\
14 & Mudflat & 79 & 1.98 \\
15 & Walking on the mudflats & 75 & 1.88 \\
\hline
\end{tabular}

The associations with the stimulus word "mudflat hiking tour" can be seen in Tables 4 and 5. Again, a significant relationship $\left(\chi^{2}(132)=1072.990, p<0.001\right)$ was found between the two variables, and, according to [81], a moderately strong effect $(V=0.392)$.

Table 4. Stimulus word: mudflat hiking tour; sample: coast; associations: $n=3993$; associations/individual: 2.38 .

\begin{tabular}{cccc}
\hline Item & Association & $\mathbf{n}$ & $\mathbf{\%}$ \\
\hline 1 & Walking on the mudflats & 492 & 12.32 \\
2 & Mudflat guides & 295 & 7.39 \\
3 & Discover/Explore tidal flats & 281 & 7.04 \\
4 & Mud/Sludge & 201 & 5.03 \\
5 & Personal dislike & 173 & 4.33 \\
6 & Rubber boots & 165 & 4.13 \\
\hline
\end{tabular}


Table 4. Cont.

\begin{tabular}{cccc}
\hline Item & Association & $\mathbf{n}$ & $\mathbf{\%}$ \\
\hline 7 & Knowledge transfer & 154 & 3.86 \\
8 & Group of people/School class & 148 & 3.71 \\
9 & Lugworm & 144 & 3.61 \\
10 & Joy/Pleasure & 139 & 3.48 \\
11 & Mussels & 118 & 2.96 \\
12 & Barefoot & 114 & 2.85 \\
13 & Dangers/Dangerous & 111 & 2.78 \\
14 & Sinking in/Getting stuck & 99 & 2.48 \\
15 & Ebb & 93 & 2.33 \\
\hline
\end{tabular}

Table 5. Stimulus word: mudflat hiking tour; sample: inland; associations: $n=2983$; associations/individual: 2.07 .

\begin{tabular}{cccc}
\hline Item & Association & $\mathbf{n}$ & \% \\
\hline 1 & Walking on the mudflats & 470 & 15.76 \\
2 & Rubber boots & 252 & 8.45 \\
3 & Term is unknown & 162 & 5.43 \\
4 & Lugworm & 161 & 5.40 \\
5 & Personal dislike & 147 & 4.93 \\
6 & Mud/Sludge & 142 & 4.76 \\
7 & Crabs & 131 & 4.39 \\
8 & Ebb & 127 & 4.26 \\
9 & Mudflat guides & 105 & 3.52 \\
10 & Dangers/Dangerous & 99 & 3.32 \\
11 & Dirt/Filth & 81 & 2.72 \\
12 & Animals & 64 & 2.15 \\
13 & Sinking in/Getting stuck & 61 & 2.04 \\
14 & Joy/Pleasure & 59 & 1.98 \\
15 & Sand & 57 & 1.91 \\
\hline
\end{tabular}

The results of the quantitative content analysis of the associations with the stimulus word "tides" are shown in Tables 6 and 7. Using the $\chi^{2}$-test, a significant relationship was found between students' place of residence and the associations $\left(\chi^{2}(117)=790.074\right.$, $p<0.001)$. Cramér's $V$ has a value of 0.351 . As with the other associations, this effect can again be considered moderate [81].

Table 6. Stimulus word: tides; sample: coast; associations: $n=4015$; associations/individual: 2.40 .

\begin{tabular}{cccc}
\hline Item & Association & $\mathbf{n}$ & $\mathbf{\%}$ \\
\hline 1 & Ebb & 1020 & 25.40 \\
2 & Flood & 997 & 24.83 \\
3 & (important in relation to) Moon & 219 & 5.45 \\
4 & Duration/Displacement & 183 & 4.56 \\
5 & Rising water & 168 & 4.18 \\
6 & Draining water & 161 & 4.01 \\
7 & Dangers/Dangerous & 113 & 2.81 \\
8 & High water & 107 & 2.67 \\
9 & Specific time/Daytime & 96 & 2.39 \\
10 & Low water & 83 & 2.07 \\
11 & Water & 74 & 1.84 \\
12 & Seasons/Times of day & 64 & 1.59 \\
13 & Term is unknown & 53 & 1.32 \\
14 & Swimming & 52 & 1.30 \\
15 & Walking on the mudflats & 49 & 1.22 \\
\hline
\end{tabular}


Table 7. Stimulus word: tides; sample: inland; associations: $n=2403$; associations/individual: 1.66.

\begin{tabular}{cccc}
\hline Position & Association & n & \% \\
\hline 1 & Ebb & 615 & 25.59 \\
2 & Flood & 602 & 25.05 \\
3 & (important in relation to) Moon & 197 & 8.20 \\
4 & Seasons/Times of day & 171 & 7.12 \\
5 & Earth age & 162 & 6.74 \\
6 & Term is unknown & 80 & 3.33 \\
7 & Rising water & 75 & 3.12 \\
8 & Draining water & 71 & 2.95 \\
8 & Specific time/Daytime & 71 & 2.95 \\
10 & Dangers/Dangerous & 52 & 2.16 \\
11 & Duration/Displacement & 38 & 1.58 \\
12 & Water & 35 & 1.46 \\
13 & TV series/Movie & 31 & 1.29 \\
14 & Clock & 29 & 1.21 \\
15 & Change & 23 & 0.92 \\
\hline
\end{tabular}

\subsection{Experience with the Wadden Sea}

With regard to the third research question about students' experiences of the Wadden Sea, the results are presented in Table 8 below. The school dimension is represented by the amount of the topic's thematization in the context of lessons. Out-of-school experiences with the class can be experienced through a school excursion to the Wadden Sea, and the private dimension focuses on visiting the Wadden Sea during leisure time (coast sample) or on vacation (inland sample).

Table 8. School dimension: thematization of the Wadden Sea in school lessons (coast $n=1675$, inland $n=1444)$.

\begin{tabular}{ccc}
\hline Subject & Coast (\%) & Inland (\%) \\
\hline Geography & 15.16 & 7.13 \\
Biology & 12.30 & 2.42 \\
Natural sciences & 22.39 & 1.18 \\
Social sciences & 2.93 & 0 \\
German & 0.96 & 1.52 \\
Physics & 0.54 & 0.21 \\
Religion & 0.30 & 0 \\
History & 0.18 & 0 \\
Sports & 0.18 & 0 \\
English & 0.06 & 0 \\
Indication without subject & 3.34 & 0 \\
No subject thematization & 41.31 & 87.05 \\
Not specified & 0.36 & 0.48 \\
\hline
\end{tabular}

Table 8 shows the thematization of the Wadden Sea in lessons in the respective school subjects.

The out-of-school perspective is measured by the number of students' reported excursions with their school classes to the Wadden Sea. Thus, students were asked if such an excursion had taken place. (Table 9)

Table 9. Out-of-school with the class dimension: excursion to the Wadden Sea with one's school class (coast $n=1675$, inland $n=1444$ ).

\begin{tabular}{ccc}
\hline Subject & Coast (\%) & Inland (\%) \\
\hline Yes & 45.25 & 7.06 \\
No & 51.76 & 91.20 \\
Not specified & 2.99 & 1.73 \\
\hline
\end{tabular}


In addition to these considerations in the context of school, the survey also focused on private experiences and asked whether an individual had ever visited the Wadden Sea. (Table 10)

Table 10. Private dimension: visits to the Wadden Sea outside the school context (coast $n=1675$, inland $n=1444$ ).

\begin{tabular}{ccc}
\hline Subject & Coast (\%) & Inland (\%) \\
\hline Never & 15.70 & 57.20 \\
1-2 times & 29.25 & 24.79 \\
3-6 times & 19.46 & 9.42 \\
6-10 times & 8.18 & 3.32 \\
More than 10 times & 27.10 & 4.71 \\
Not specified & 0.30 & 0.55 \\
\hline
\end{tabular}

\section{Discussion}

Different aspects of the results presented in the tables will be discussed below on various levels. Some selected results for each case are considered generally, in relation to the concrete stimulus word (question 1), as well as in relation to the two student samples (question 2). At selected points, a comparison of the results with the literature will be made. Since there is only one other study in the specific research field, the references will generally take place in a superordinate context. After a category is mentioned, the percentage of the respective associations with respect to the corresponding total number is given in parentheses. The value for the coast sample is given first, followed by the corresponding value for the inland sample.

This is followed by a discussion of the results from the data collected regarding experiences of the Wadden Sea (question 3).

\subsection{Stimulus word "Wadden Sea"}

The term "Wadden Sea" primarily evokes associations of the category "mud/sludge" $(9.44 \% / 9.57 \%)$ from the students of both samples. Almost every tenth association can be assigned to this category. Since this can be determined regardless of the respondents' place of residence, the relevance becomes particularly clear. A survey with a comparable methodological approach collected associations from vacation guests at the Schleswig-Holstein Wadden Sea National Park regarding this stimulus word, confirming this finding [82]. Equally characteristic seems to be the term "lugworm" (7.77\%/5.68\%), as it is mentioned in meaningful numbers in both samples. This result can substantiate Gätje's remarks [82] regarding the symbolic power of the lugworm. In another study on the perceptions of marine ecosystems, it was shown that the knowledge of characteristic species is by no means accompanied by knowledge about them [83]. In general, there is an overlap of ten categories in the two student sample groups from the present study. Therefore, these ten categories seem to represent frequent associations with the Wadden Sea that are independent of the place of residence. It is striking that associations of the two categories "ebb" (4.75\%/9.47\%) and "flood" (3.53\%/7.52\%) are mentioned about twice as often by inland-sample students as by coastal-sample students. This indicates that related contents have a great or even greater relevance among the respondents without residential proximity. The survey of vacationers, in which the term "ebb" (predominantly in combination with "flood") was mentioned most frequently, confirms this finding [82]. The ratio shown with regard to the number of associations in both samples also applies to the category "sea" $(3.31 \% / 6.46 \%)$. The naming of these associations can certainly be explained by students' physical proximity to the subject of the stimulus word. Conversely, the category "water" (7.06\%/3.84\%) demonstrates considerably higher importance in the coast sample.

Another focus is analyzing the five categories which are each found in the rankings of only one of the two student sample groups and are therefore an indication of differences. For example, the inland sample students frequently mention term associations that can be 
considered unrelated to the subject. The naming of such associations is not uncommon [70] and offers a central connecting point, especially for this topic. The category "Wadding (cotton filling)" (3.57\%) is an indication that the students of the inland sample again made a derivation regarding the literal origin of the stimulus word "Wadden Sea". In contrast, these associations, which are not technically comprehensible, do not have any significant meaning for the students in the coast sample. Following this reasoning, the category "Baltic Sea" (2.24\%) should be used. There is no Wadden Sea on the Baltic Sea. Thus, the associations assigned to this category are also to be considered false from a professional perspective. This assessment is supported by the category "North Sea" $(2.12 \% / 5.63 \%)$, because this is much more frequent and therefore more meaningful in the inland sample than in the coast sample. One possible explanation is that students from the inland sample associate the Wadden Sea with the location in the North Sea, while for the students from the coast sample, this could have been taken as a matter of course due to it being their own place of residence, and would explain the lower number of mentions. Furthermore, it is very surprising that $3.87 \%$ of the associations from the inland sample showed the Wadden Sea to be unknown to the individual. These descriptions of complete unfamiliarity prove the low significance that the Wadden Sea has for these inland students and is an indication of a low level of knowledge about the ecosystem. In another study in the context of the perception of marine ecosystems, it was similarly demonstrated that the level of notoriety is an important prerequisite for awareness [84]. In general, some marine habitats with their special features seem to be unknown in the general population [85]. Another indication of this is the category "ships" (5.63\%), which was only mentioned frequently in the inland sample. This also suggests a direct relation to the stimulus word on the literal level and can hardly be directly related to the Wadden Sea in a technical sense.

Conversely, the categories that only emerge from the ranking of the associations of students from the coast sample can be explained by experiences related to the Wadden Sea. In particular, this explanation is suggested by the categories "crabs" (5.13\%), "mussels" $(4.80 \%)$, "birds" $(2.24 \%)$ and "animals" $(6.02 \%)$. The category "silt" (3.49\%) indicates the students' knowledge of a technical term that can also be understood as a technically correct representation of the associations for the previously mentioned category, "mud". In this case, it is precisely the out-of-school experiences with an ecosystem that can have a positive influence on knowledge and can thus be used as an explanation for the presenting of the technical term [86]. A concrete reference is in the discussion on experiences.

\subsection{Stimulus Word "Mudflat Hiking Tour"}

According to the experts, this stimulus word should be an indication of whether students potentially have experience of the Wadden Sea. From the results, we should be able to examine the success of this intention, while at the same time, identify any major differences between the two samples.

As in the two student sample groups' previous rankings for the word "Wadden Sea", there is also an overlap of ten categories between the two student sample groups for the word "mudflat hiking tour" (which is one word in German). The students in both samples primarily chose a definitional approach with the associations. Therefore, the category "walking on the mudflats" $(12.32 \% / 15.76 \%)$ is very relevant. In addition, associations that were assigned to the category "mudflat guides" (7.39\%/3.52\%) appear to be important, although these were given significantly more frequently by the coast sample. Associations regarding the category "discover/explore the Wadden Sea" (7.04\%) were the third most often given in the coast sample, while they were missing from the ranking of the inland sample. This proves both the great meaning of a dimension directed towards the exploration of the Wadden Sea for students from the coast sample, as well as the complete unimportance of this aspect for the other sample. The relevance of such activities in nature can be illustrated with empirical research results. For example, primary nature experiences have been found to have a positive influence on physical, psychological, and social health [87]. Furthermore, experiences in nature are formative for fostering 
understanding and attitudes [88-90]. This discrepancy between the two groups is further confirmed by the category "knowledge transfer" $(3.86 \%)$, which is also found exclusively in the association ranking from the coast sample. This category illustrates the importance of the knowledge that is imparted during a mudflat walk and the relevance of the educational aspect of mudflat walks. Knowledge about the Wadden Sea is a prerequisite for protecting this ecosystem [37], and therefore acquires special relevance.

The mudflat hikes usually take place in a group setting; this is only referenced, along with references to the school level, in the coast sample in the context of the category "group of people/school class" (3.71\%). Likewise, associations that can be assigned to the categories "mussels" (2.96\%) and "barefoot" (2.85\%) are exclusively emphasized to a particular degree by students in the coast sample. In particular, "barefoot" suggests the relevance of a mudflat hike as an experience, although the category "rubber boots" $(4.13 \% / 8.45 \%)$ is shown as meaningful from the data of both student samples. One reason for inland students frequently mentioning associations in this category could be a general association of rubber boots with the mudflat hikes.

The frequent mention of associations describing a "personal dislike" (4.33\%/4.93\%) of mudflat walks, present in both samples, is remarkable. It is unclear to what the dislike specifically refers. Since negative associations in connection with the ecosystem of the Wadden Sea would certainly also have arisen with the first stimulus word (in a more or less frequent execution), the (didactic) designs of mudflat tours or the general environment (learning) could be starting points for related explanations. On the other hand, the category "dirt/filth" $(2.72 \%)$, which plays a non-negligible role in the inland sample, speaks to a general dislike of the Wadden Sea. Such forms of dislike can be transferred to the research area of disgust in subject didactics. In some empirical studies, the regional origin of the students was taken into account in addition to their disgust for animals. It was independently found that children from the city were disgusted by a larger number of animals than were children from the countryside [91,92]. This finding may be an explanation for the greater blanket disgust of the mudflats, or the higher negative account of mudflat walks by coastal students than by those from inland. In this context, it should be noted that, contrary to these associations, associations from the category "joy/pleasure" $(3.48 \% / 1.98 \%)$ also occur in both student sample rankings. Ultimately, there seems to be a very heterogeneous picture of mudflat walks.

In third place, in the ranking of categories formed based on the inland student sample associations, is the category "term is unknown" $(5.43 \%)$. Due to the percentage of students in this sample who are completely unfamiliar with the Wadden Sea, this finding is a further confirmation of the results already discussed and are consistent with the literature [85]. Furthermore, they illustrate a high degree of unfamiliarity on an experiential level.

Students from both samples also mention the potential dangers of the Wadden Sea in the category "dangers/dangerous" (2.78\%/3.32\%). The more frequent mentioning in the inland sample can be considered surprising, since many of them have no personal experience with the Wadden Sea.

\subsection{Stimulus Word "Tides"}

For this stimulus word, more than for any other, categories can be formed with a prominent meaning in the rankings for both student sample groups. The categories "ebb" $(25.40 \% / 25.59 \%)$ and "flood" (24.83\%/25.05\%) account for more than half of all associations in both samples. These terms seem to be a special domain in relation to the stimulus word, completely independent of the students' place of residence. Based on the respective processes, associations from the categories "rising water" $(4.18 \% / 3.12 \%)$ and "draining water" $(4.01 \% / 2.95 \%)$ can be understood as belonging to this field.

In both samples, the "(important in relation to) the moon" category $(5.45 \% / 8.20 \%)$ is also highlighted as central. The stimulus word thus seems to have elicited a content-related or subject-related association category, as expected. The finding that students provide subject associations confirms the results of other association studies (e.g., [49-51,53]). Similarly, 
the category "duration/displacement" $(4.56 \% / 1.58 \%)$ is another example of a subjectrelated association category. In view of the, generally, much more frequent naming of associations overall in the coast sample, it is not surprising that the students of the coast sample also thematize their associations on a content-related level. Likewise, the terms "high water" (2.67\%) and "low water" $(2.07 \%)$ as technical terms have content-related relevance. However, these can only be found in the ranking of the categories which were formed from the associations of students from the coast sample. In the ranking from the inland sample, there are no further categories that clearly point to a technical theme. Only the category "specific time/daytime" $(2.39 \% / 2.95 \%)$, which is again found in the rankings of both samples, might also be considered technical. As another study [84] shows, in terms of identified knowledge, the familiarity or unfamiliarity of the ecosystem could account for the difference in terms of the different numbers of subject associations.

The lack of specialized scientific concepts on the Wadden Sea ecosystem is also evident regarding the stimulus word "tides". The category "term is unknown" $(1.32 \% / 3.33 \%)$ is even in the rankings of both samples, with regard to this stimulus word. Again, it is the inland sample students who name associations related to this category more frequently. However, it is astonishing that, even for students living near the Wadden Sea, this term seems to be unknown to a considerable number of students. This impression is confirmed by categories that take associations not related to the subject into account. In the category "seasons/times of day" (1.59\%/7.12\%), a literal derivation from the stimulus word "tides" (in German, Gezeiten) is repeatedly recognizable (The word Zeit in German means "time"). Particularly in the inland sample, this category acquires relevance, since it occupies fourth place in the ranking. In fifth place in the category ranking from this sample is the next category, with associations unrelated to the subject. In the category "Earth age" (6.74\%), the literal derivation of the term is associated with a historical dimension (in German, Erdzeitalter). In the ranking of categories from the coast sample, this category is not present, in contrast to the category "seasons/times of day". This also applies to the categories "TV series/film" $(1.29 \%)$ and "clock" (1.21\%), which again suggest a literal derivation of the associations, or, based on this, links to the titles of TV series or films, and can therefore by no means be considered technical. Other research on adults' perceptions of marine ecosystems has found that respondents do not feel adequately informed about selected technical content [93]. Thus, a lack of school-based thematization of tidal flats (see the discussion of experiences) may be the cause of these associations. Participants in another study mentioned increasing the importance of environmental education as a useful tool for marine conservation [94].

In the coast sample, however, regarding the stimulus word "tides", the categories "swimming" $(1.30 \%)$ and "walking on the mudflats" $(1.22 \%)$ focus on an experienceoriented level, as is similar in the associations with the previous stimulus word. These or comparable categories are not found in the ranking of the inland sample, so the corresponding associations are of little meaning for inland students.

\subsection{Experience of the Wadden Sea}

The results illustrate in a quantitative way the different student experiences of the Wadden Sea in the three dimensions considered (in-school, out-of-school, and privately). The data can be found in Tables 8-10.

It can be seen that $87.05 \%$ of the students from the inland sample have not yet covered the topic of the Wadden Sea at school. In contrast, only $41.31 \%$ of the students in the coast sample have not been taught about the Wadden Sea. Surprisingly, the Wadden Sea was mainly considered in geography $(7.13 \%)$ and less often in biology $(2.42 \%)$ or science $(1.18 \%)$ among the surveyed inland students. Among the surveyed students from the coast, the Wadden Sea was primarily addressed in science $(22.39 \%)$ and in geography $(15.16 \%)$ and biology $(12.30 \%)$. In the coast sample, a perspective in social science subjects also has meaning $(2.93 \%)$, whereas in the inland sample, this is not the case $(0 \%)$. The relevance of the subject in German $(1.52 \%)$ is higher in the inland sample than in the coast sample 
$(0.96 \%)$. This described relationship between the place of residence and school-based thematization is statistically significant $\left(\chi^{2}(12)=784.156, p<0.001\right)$. Cramér's V assumes a value of 0.501 . Thus, it is a great effect [81].

With regard to out-of-school experiences with the class, it is clear that $45.25 \%$ of the surveyed students in the coast sample have already been to the Wadden Sea with their school class. It is not surprising that this number is higher than in the inland sample $(7.06 \%)$, due to the close proximity. Nevertheless, it could hardly be assumed in advance that there would be such a high number of out-of-school experiences. This relationship also exhibits statistical significance $\left(\chi^{2}(2)=587.558, p<0.001\right)$. The effect size is moderate, based on $\mathrm{V}=0.434$ [81]. Biology education research has determined that out-of-school experiences correlate with an interest in biology [95]. Likewise, the subject terms associated by the students in the coast sample could be explained by this finding.

The argument of location-dependency can also be used with regard to private experiences, since $57.20 \%$ of the surveyed students from the inland sample had not yet been to the Wadden Sea privately. Nevertheless, with 34.21\%, more than one-third of them had already been there up to three times (e.g., during a vacation). Yet it is astonishing that $15.70 \%$ of the students from the coast sample had not even been to the Wadden Sea, although they live nearby. This shows that even the immediate spatial proximity of a student's place of residence to the ecosystem does not automatically go hand in hand with the student experiencing nature in the immediate vicinity. After all, 27.10\% of the students from the inland sample have been to the Wadden Sea more than 10 times. Also with respect to this dimension, the correlation is significant $\left(\chi^{2}(5)=705.453, p<0.001\right)$, and, according to [81], to be presented as a moderate-strong effect due to a Cramér's V value of 0.576 .

\section{Outlook}

The present study provides initial insight into the students' conceptions of the Wadden Sea. In summary, it should be emphasized that this study provides many starting points for further studies. These could, for example, be directed towards in-depth research of the students' conceptions - as already discussed in the methodological part of this study. In this way, those students' word associations that could be considered incorrect from a technical perspective could be investigated in more detail, and possible explanations could be identified. For this purpose, it would make sense to conduct an interview study, to allow intensive discussions with selected students. From a research methodological perspective, this procedure would be associated with the recording of conceptions. The associations identified in this study are necessary for developing an interview guideline. These have opened up the research area and can subsequently be used as a basis for designing the guideline. Following this, it would again be possible to discuss the results of this paper by increasing the results from the interview study. This will potentially provide new points of contact in terms of content, which can explain the identified associations in greater depth.

With regard to the limitations of the present study, it is necessary to focus once again at this point on the methodological implementation. The method was selected after intensive consideration in a long, discursive process. Although the results provide initial, far-reaching insights into the learners' perceptions of the Wadden Sea, they are clearly limited in terms of their depth, so that further research is needed. With a follow-up study, which in turn presupposes the implemented methodological approach, the findings can be discussed. In this context, it would also make sense to investigate the students' high degree of unfamiliarity with the Wadden Sea, including knowledge of its technical content. Another limitation inevitably results from the methodological implementation. As described, the selection of the stimulus words was an intensive process, with the participation of experts from different fields. The results obtained finally prove the general relevance of this choice. Nevertheless, it cannot be determined which associations would have been elicited by other stimulus words. This question could be addressed following a more in-depth assessment of the learners' conceptions. To the extent that the conceptions present divergent concepts, other terms could be evaluated as meaningful stimulus words. 
Thus, a renewed performance of a word association test with modified association words may also be useful.

Another approach to the topic is the development of the educators' perspective. It is possible to survey educators from different disciplines regarding the Wadden Sea. With regard to a methodical concretization, interviews are again a good possibility. For this project, the associations again provide an important basis because they can be discussed with the experts and evaluated by them. Due to the practical experiences with out-of-school learning opportunities on the Wadden Sea, further additions to the learner perspective are consequently possible, although the educator perspective can be examined in parallel. Finally, it is essential for the didactical understanding of the Wadden Sea to identify both perspectives.

In addition, against the background of biology didactics, considering the Wadden Sea as a place of learning is particularly relevant in order to, among other things, illuminate and possibly explain the discrepancy between the students' dislike and their positive feelings toward the Wadden Sea. Other ecosystems, such as the forest, have been investigated for their potential and limitations as learning sites in various didactic research projects. Comparable studies on the Wadden Sea are missing. For this purpose, a variety of valid measurement instruments are available, to consider constructs from the fields of psychology and environmental education/education for sustainable development. Word associations can be used for the selection of appropriate study designs, including the choice of measurement instruments. These offer versatile starting points, in that, for example, the areas of "exploratory learning", "experiencing nature", "joy", "knowledge of species" or also "disgust" have been opened up. Results from corresponding studies can again be linked to the word associations to enable further discussions.

Author Contributions: Conceptualization, T.S.; methodology, T.S.; software, T.S.; validation, N.G.; formal analysis, T.S.; investigation, T.S.; resources, T.S.; data curation, T.S.; writing—original draft preparation, T.S.; writing—review and editing, N.G.; visualization, T.S.; supervision, N.G.; project administration, T.S.; funding acquisition, T.S. All authors have read and agreed to the published version of the manuscript.

Funding: We acknowledge support for the publication costs by the Open Access Publication Fund of Bielefeld University.

Institutional Review Board Statement: Not applicable.

Informed Consent Statement: Not applicable.

Data Availability Statement: The data presented in this study are available on request from the corresponding author.

Conflicts of Interest: The authors declare no conflict of interest.

\section{References}

1. Hofstede, J. Danish-Germany-Dutch Wadden Environments. In the Physical Geography of Western Europe, Reprinted; Koster, E.A., Ed.; Oxford Univ. Press: Oxford, UK, 2005; pp. 185-205, ISBN 9780199277759.

2. Reise, K.; Baptist, M.; Burbridge, P.; Dankers, N.; Flemming, B.; Oost, A.P.; Smit, C. The Wadden Sea-A Universally Outstanding Tidal Wetland. Wadden Sea Ecosyst. 2010, 7, 7-23.

3. Horn, S.; Schwemmer, P.; Mercker, M.; Enners, L.; Asmus, R.; Garthe, S.; Asmus, H. Species composition of foraging birds in association with benthic fauna in four intertidal habitats of the Wadden Sea. Estuar. Coast. Shelf Sci. 2020, 233, 106537. [CrossRef]

4. Südbeck, P.; Bunje, J. Die Trilaterale Wattenmeerkooperation-Paradebeispiel für eine erfolgreiche grenzüberschreitende Zusammenarbeit im Ökosystemschutz. In Grenzüberschreitende und Bundesländer Übergreifende Zusammenarbeit von Nationalen Naturlandschaften: Dokumentation Ausgewählter Beiträge Einer BfN-Tagung vom 12-13 November 2013 in Fulda; Scherfose, V., Gehrlein, U., Milz, E., Eds.; Bundesamt für Naturschutz (BfN): Bonn-Bad Godesberg, Germany, 2015; pp. 59-82, ISBN 978-3-89624-140-5.

5. Brunckhorst, H. Biosphärenreservat Schleswig-Holsteinisches Wattenmeer. In Biosphärenreservate in Deutschland: Leitlinien für Schutz, Pflege und Entwicklung; Ständige Arbeitsgruppe der Biosphärenreservate in Deutschland; Springer: Berlin/Heidelberg, Germany, 1995; pp. 113-119, ISBN 978-3-642-63367-6.

6. UNESCO. Report of Decisions: Extract of the Report Agenda Item 8B-Nominations to the World Heritage List Decision 33 COM 8B.4; UNESCO: Seville, Spain, 2009. 
7. UNESCO. Decisions Adopted; UNESCO: Doha, Qatar, 2014.

8. Schmidt, A.; Wehrmann, A.; Dittmann, S. Population dynamics of the invasive Pacific oyster Crassostrea gigas during the early stages of an outbreak in the Wadden Sea (Germanyy). Helgol. Mar. Res. 2008, 62, 367-376. [CrossRef]

9. Zipperle, A.M.; Coyer, J.A.; Reise, K.; Stam, W.T.; Olsen, J.L. An evaluation of small-scale genetic diversity and the mating system in Zostera noltii on an intertidal sandflat in the Wadden Sea. Ann. Bot. 2011, 107, 127-134. [CrossRef] [PubMed]

10. Shan, T.; Pang, S.; Wang, X.; Li, J.; Su, L.; Schiller, J.; Lackschewitz, D.; Hall-Spencer, J.M.; Bischof, K. Genetic analysis of a recently established Undaria pinnatifida (Laminariales: Alariaceae) population in the northern Wadden Sea reveals close proximity between drifting thalli and the attached population. Eur. J. Phycol. 2019, 54, 154-161. [CrossRef]

11. Clausen, S.; Christian, A. Concept Mapping als Messverfahren für den außerschulischen Bereich: Concept Mapping for Measurement in a non scholar context. J. Didakt. Biowiss. (F) 2012, 3, 18-31.

12. Paatsch, U. Macht und Ohnmacht des Evaluators: Das Beispiel Nationalparkzentrum Wilhelmshaven "Das Wattenmeerhaus". In (Umwelt-)Ausstellungen und ihre Wirkung: Auf dem Weg zu Effektiven Ausstellungen; Tagung vom 29-31 January 1998 im Staatlichen Museum für Naturkunde und Vorgeschichte Oldenburg; Scher, M.A., Ed.; Isensee: Oldenburg, Germany, 1998; pp. 152-171, ISBN 9783895985522.

13. Groß, J. Die Vermittlung der Nationalparkidee-Außerschulische Umweltbildung und BNE in der Evaluation. In Naturschutz und Bildung für Nachhaltige Entwicklung: Fokus: Außerschulische Lernorte; Ergebnisse des F+E-Vorhabens "Bildung für Nachhaltige Entwicklung (BNE)—Positionierung des Naturschutzes"; Lucker, T., Ed.; Bundesamt für Naturschutz: Bonn-Bad Godesberg, Germany, 2009; pp. 189-222, ISBN 978-3-7843-3974-0.

14. Groß, J. Orte zum Lernen-Ein kritischer Blick auf außerschulische Lehr-/Lernprozesse. In Ausserschulische Lernorte—Positionen aus Geographie, Geschichte und Naturwissenschaften; Messmer, K., von Niederhäusern, R., Rempfler, A., Wilhelm, M., Eds.; LIT: Wien, Austria; LIT: Berlin, Germany, 2011; pp. 25-49, ISBN 9783643801081.

15. Brauer, L.; Hößle, C. Acquiring diagnostic skills in the field of experimentation in the Wadden Sea's Teaching \& Learning Laboratory. In Challenges in Biology Education Research: [A Selection of Papers Presented at the XIth Conference of European Researchers in Didactics of Biology (ERIDOB), Karlstad, 5-9 September 2016]; Gericke, N., Grace, M., Eds.; University Printing Office: Karlstad, Sweden, 2018; pp. 256-272, ISBN 978-91-7063-945-6.

16. Saathoff, A.; Hößle, C. Teaching \& Learning Labor Atories in Biology Teacher Education: Analysis of Teaching Reflections. In Biology Education Research. Contemporary Topics and Directions; Puig, B., Anaya, P.B., Quílez, M.J.G., Eds.; Servicio de Publicaciones Universidad de Zaragza: Zaragza, Spain, 2020; pp. 309-322, ISBN 9788416723973.

17. Weusmann, B.; Käpnick, F.; Brüning, A.-K. Lehr-Lern-Labore in der Praxis: Die Vielfaltrealisierter Konzeptionen und ihre Chancenfür die Lehramtsausbildung. In Lehr-Lern-Labore; Priemer, B., Roth, J., Eds.; Springer: Berlin/Heidelberg, Germany, 2020; pp. 27-45, ISBN 978-3-662-58912-0.

18. Wübben, A. Aus der Meeresforschung in die Nationalparkhäuser: Entwicklung, Erprobung und Implementierung Neuer Umweltbildungsangebote zum Thema ,Gefährdung und Schutz des UNESCO Weltnaturerbes Wattenmeer; Carl von Ossietzky Universität Oldenburg, Institut für Biologie und Umweltwissenschaften: Oldenburg, Germany, 2019.

19. Großschedl, J.; Mahler, D.; Kleickmann, T.; Harms, U. Content-Related Knowledge of Biology Teachers from Secondary Schools: Structure and learning opportunities. Int. J. Sci. Educ. 2014, 36, 2335-2366. [CrossRef]

20. Mahler, D.; Großschedl, J.; Harms, U. Opportunities to Learn for Teachers' Self-Efficacy and Enthusiasm. Educ. Res. Int. 2017, 2017, 1-17. [CrossRef]

21. Mahler, D.; Großschedl, J.; Harms, U. Using doubly latent multilevel analysis to elucidate relationships between science teachers' professional knowledge and students' performance. Int. J. Sci. Educ. 2017, 39, 213-237. [CrossRef]

22. Müller, N.; Elster, D. Promotion Teachers Students' System Competence by the Development of a Syndrome Approach in an Interdisciplinary Seminar. In Proceedings of the Conference Proceedings: New Perspectives in Science Education: 7th Conference Edition, Florence, Italy, 22-23 March 2018; Pixel, Ed.; Libreriauniversitaria.it: Padova, Italy, 2018; pp. 284-289, ISBN 9788862929769.

23. Kwiatkowski, G.; Hjalager, A.-M.; Liburd, J.; Simonsen, P.S. Volunteering and collaborative governance innovation in the Wadden Sea National Park. Curr. Issues Tour. 2020, 23, 971-989. [CrossRef]

24. Bremer, S.; Graeff, P. Volunteer Management in Germany National Parks-From Random Action Toward a Volunteer Program. Hum. Ecol. 2007, 35, 489-496. [CrossRef]

25. Roskam, A.; Bliesmer, K.; Komorek, M. Phänomenologisches und analoges Lernen in Nationalparkhäusern. In Qualitätsvoller Chemie-und Physikunterricht-Normative und Empirische Dimensionen; Jahrestagung in Regensburg 2017; Maurer, C., Ed.; Universität Regensburg: Regensburg, Germany, 2018; pp. 636-639.

26. Bliesmer, K. Physik der Küste für Außerschulische Lernorte: Eine Didaktische Rekonstruktion; Carl von Ossietzky Universität Oldenburg: Oldenburg, Germany, 2020.

27. Tillmann, T.; Wunderlich, J. Brauchen wir Virtuelle Welten in den Geowissenschaften? Evaluation zum Potential Eines “Virtuellen Exkursionsführers der Nordseeküste". Mainz. Geogr. Stud. 2013, 55, $29-41$.

28. Tillmann, T.; Folkerts, M.; Frank, M.; Wunderlich, J. Konzept einer virtuellen exkursion auf die hallig hooge. Mainz. Geogr. Stud. 2013, 55, 43-57. 
29. Hinrichs, N. Vermittlungsstrategien des Weltnaturerbes Wattenmeer in der Kunst. World Herit. Arts Educ. 2012, 6/7, 113-120.

30. Hinrichs, N. Künstlerische Vermittlung des UNESCO-Welterbes Wattenmeer: Malerei, Land Art, Museumskoffer, 1. Auflage; ATHENA: Oberhausen, Germany, 2016; ISBN 978-3-89896-644-3.

31. Wagner, B. Sachlernprozesse von Kindern in interkulturellen Begegnungssituationen. J. Int. Interkult. Vgl. Erzieh. 2014, 20, 3-20.

32. Schmäing, T. Lernen im und über das UNESCO-Weltnaturerbe Wattenmeer: Die Relevanz von Kontextsensibilität und Datenvergleichbarkeit im Mixed-Methods-Design; Bielefeld University: Frankfurt, Germany; Bielefeld University: Main, Germany, 2019.

33. Schmäing, T. Das UNESCO-Weltnaturerbe Wattenmeer im Fokus von Umweltbildung und von Bildung für nachhaltige Entwicklung: Welchen Einfluss hat eine Wattexkursion auf die Umwelteinstellungen und die Naturverbundenheit von SchülerInnen? Bielefeld University: Bielefeld, Germany, 2020.

34. Gellrich, A.; Burger, A.; Tews, K.; Simon, C.; Seider, S. 25 Jahre Umweltbewusstseinsforschung im Umweltressort: Langfristige Entwicklungen und Aktuelle Ergebnisse; Umweltbundesamt: Dessau-Roßlau, Germany, 2021.

35. Lotze, H.K.; Guest, H.; O'Leary, J.; Tuda, A.; Wallace, D. Public perceptions of marine threats and protection from around the world. Ocean Coast. Manag. 2018, 152, 14-22. [CrossRef]

36. Bundesministerium für Umwelt, Naturschutz und Nukleare Sicherheit. Jugend-Naturbewusstsein 2020: Bevölkerungsumfrage zu Natur und Biologischer Vielfalt; Bundesamt für Naturschutz (BfN): Bonn, Germany, 2021.

37. Postma, D.W. Why Care for Nature? In Search of an Ethical Framework for Environmental Responsibility and Education; Springer: Dordrecht, The Netherlands, 2006; ISBN 978-1-4020-5002-2.

38. Opitz, S.T.; Blankenstein, A.; Harms, U. Student conceptions about energy in biological contexts. J. Biol. Educ. 2017, 51, 427-440. [CrossRef]

39. Sellmann, D.; Bogner, F.X. Education in Global Climate Change at a Botanical Garden: Students' Perceptions and Inquiry-Based Learning. In Climate Change and the Sustainable Use of Water Resources; Filho, W.L., Ed.; Springer: Berlin/Heidelberg, Germany, 2012; pp. 779-786, ISBN 978-3-642-22265-8.

40. Franke, G.; Bogner, F.X. Conceptual Change in Students' Molecular Biology Education: Tilting at Windmills? J. Educ. Res. 2011, 104, 7-18. [CrossRef]

41. Balgopal, M.M.; Montplaisir, L.M. Meaning making: What reflective essays reveal about biology students' conceptions about natural selection. Instr. Sci. 2011, 39, 137-169. [CrossRef]

42. Hiltmann, H.; Luhr, R. Wortassoziation und verbale Ergänzung. In Enzyklopädie der Psychologie, Themenbereich B: Methodologie und Methoden, Serie II: Psychologische Diagnostik, Band 3: Persönlichkeitspsychologie; Groffmann, K.-J., Michel, L., Eds.; Hogrefe Verl. für Psychologie: Göttingen, Germany, 1982; pp. 373-429, ISBN 3801705013.

43. Forrest, D. The first experiments on word association. Bull. Br. Psychol. Soc. 1977, 30, 40-42.

44. Woodworth, R.; Schlosberg, H. Experimental Psychology: Revised Edition; Holt, Rinehart and Winston: New York, NY, USA; Holt, Rinehart and Winston: Chicago, IL, USA; Holt, Rinehart and Winston: San Francisco, CA, USA; Holt, Rinehart and Winston: Toronto, ON, Canada, 1965.

45. Warren, H.C. A History of the Association Psychology; Charles Scribner's Sons: New York, NY, USA, 1921.

46. Beatty, I.D.; Gerace, W.J.; Dufresne, R.J. Measuring and Modeling Physics Students' Conceptual Knowledge Structures through Term Association Times; UMass Physics Education Research Group: Amherst, MA, USA, 2002.

47. Bogner, F.X. Assoziationstests und Ökologieunterricht/Umwelterziehung am außerschulischen Lernort. Verh. Ges. Okol. 1995, 24, 465-470.

48. Tsai, C.-C.; Huang, C.-M. Exploring students' cognitive structures in learning science: A review of relevant methods. J. Biol. Educ. 2002, 36, 163-169. [CrossRef]

49. Burger, J. Schülervorstellungen zu "Energie im Biologischen Kontext"-Ermittlungen, Analysen und Schlussfolgerungen: Ein Beitrag zur Verminderung von Lernschwierigkeiten im Biologieunterricht der Sekundarstufen Durch Vermehrte Berücksichtigung von Schülervorstellungen zu "Energie im biologischen Kontext" in Konstruktivistischer Lernumgebung; Universität Bielefeld: Bielefeld, Germany, 2001.

50. Duit, R. Energievorstellungen. Nat. Unterr. Phys.Chem. 1986, 34, 7-9.

51. Schaefer, G. Concept Formation in Biology: The Concept 'Growth'. Eur. J. Sci. Educ. 1979, 1, 87-101. [CrossRef]

52. Reitschert, K.; Hößle, C. Wie Schüler ethisch bewerten: Eine qualitative Untersuchung zur Strukturierung und Ausdifferenzierung von Bewertungskompetenz in bioethischen Sachverhalten bei Schülern der Sek. I. Z. Didakt. Nat. 2007, 13, $125-143$.

53. Dieser, O.; Bogner, F.X. Intervention Impact on Young Students' Associations about Wolf and Lynx. Soc. Anim. 2019, 27, 544-574. [CrossRef]

54. Bogner, F.X.; Wiseman, M. Association tests and outdoor ecology education. Eur. J. Psychol. Educ. 1997, 12, 89-102. [CrossRef]

55. Kurt, H.; Ekici, G.; Aktas, M.; Aksu, O. Determining Biology Student Teachers' Cognitive Structure on the Concept of "Diffusion" through the Free Word-Association Test and the Drawing-Writing Technique. IES 2013, 6. [CrossRef]

56. Kurt, H. Determining Biology Teacher Candidates' Conceptual Structures about Energy and Attitudes Towards Energy. J. Balt. Sci. Educ. 2013, 12, 399-423.

57. Kurt, H. Biology student teachers' cognitive structure about "Living thing”. Educ. Res. Rev. 2013, 8, 871-880.

58. Dikmenli, M. Biology Student Teachers' Conceptual Frameworks regarding Biodiversity. Education 2010, 130, 479-489.

59. Dikmenli, M. Biology students' conceptual structures regarding global warming. Energy Educ. Sci. Technol. Part B Soc. Educ. Stud. 2010, 2, 21-38. 
60. Bahar, M.; Johnstone, A.H.; Sutcliffe, R.G. Investigation of students' cognitive structure in elementary genetics through word association tests. J. Biol. Educ. 1999, 33, 134-141. [CrossRef]

61. Kostova, Z. Word Association Test for Studying Conceptual Structures of Teachers and Students. Bulg. J. Sci. Educ. Policy 2008, 2, 209-231.

62. Schaefer, G. Begriffsforschung als Mittel zur Unterrichtsgestaltung. In Sprache und Verstehen im Biologieunterricht: Bericht Über Die 8. Internationale Arbeitstagung der Sektion Fachdidaktik Biologie im VDBiol zum Thema "Sprache und Verstehen im Biologieunterricht" in Bad Zwischenahn vom 30.09.91 bis 04.10.91; Entrich, H., Ed.; Leuchtturm-Verl.: Alsbach, Germany; Leuchtturm-Verl.: Bergstr, Germany, 1992; pp. 128-139, ISBN 3-88064-221-4.

63. Maichle, U. Wissen, Verstehen und Problemlösen im Bereich der Physik; Lang: Frankfurt am Main, Germany, 1985; ISBN 3-8204-5642-2.

64. Deese, J. The Structure of Associations in Language and Thought; John Hopkins Press: Baltimore, MD, USA, 1965.

65. Rothe, H.-J. Wissensdiagnose auf Basis von Assoziieren und Struktur-Legen. In Handbuch Kompetenzmessung: Erkennen, Verstehen und bewerten von Kompetenzen in der Betrieblichen, Pädagogischen und Psychologischen Praxis; Erpenbeck, J., von Rosenstiel, L., Eds.; Schäffer-Poeschel: Stuttgart, Germany, 2003; pp. 114-125, ISBN 3-7910-2106-0.

66. Bortz, J.; Döring, N. Forschungsmethoden und Evaluation: Für Human-und Sozialwissenschaftler, 4th ed.; Springer: Berlin/Heidelberg, Germany, 2006; ISBN 978-3-540-33305-0.

67. Mayring, P. Qualitative Inhaltsanalyse: Grundlagen und Techniken, 12., Überarbeitete Auflage; Beltz Verlag: Weinheim, Germany; Beltz Verlag: Basel, Switzerland, 2015; ISBN 978-3-407-29393-0.

68. Crossley, A.; Hirn, N.; Starauschek, E. Schülervorstellungen zur Energie-Eine Replikationsstudie. In Didaktik der Physik: Bochum 2009; CD Tagungsbeiträge zur Frühjahrstagung der DPG, des Fachverbandes Didaktik der Physik der Deutschen Physikalischen Gesellschaft, Bochum 2009; Beiträge zur MNU-Tagung, Regensburg 2009, Deutscher Verein zur Förderung des Mathematischen und Naturwissenschaftlichen Unterrichts, 1st ed.; Nordmeier, V., Ed.; Lehmanns Media: Berlin, Germany, 2009; ISBN 978-3-86541-371-0.

69. Müller, W.G. Ein interkultureller Vergleich affektiver und assoziativer Wortbedeutungen. Sprache Kognit. 1998, 17, 73-88.

70. Schaefer, G. Die Wissenschaftssprache der Biologie im Lichte "inklusiven Denkens". In Kommunikative Grundlagen des Naturwissenschaftlichen Unterrichts; Schaefer, G., Loch, W., Schaefer-Loch, Eds.; Beltz: Weinheim, Germany, 1980; pp. 99-134, ISBN 3-40769120-3.

71. Flick, U. An Introduction to Qualitative Research, 4th ed.; Rev., Expanded and Updated; Sage: Los Angeles, CA, USA, 2009; ISBN 978-1-84787-323-1.

72. Schreier, M. Fallauswahl. In Handbuch Qualitative Forschung in der Psychologie; Mey, G., Mruck, K., Eds.; Springer: Wiesbaden, Germany, 2020; pp. 19-39, ISBN 978-3-658-26886-2.

73. Ritchie, J.; Lewis, J.; Gillian, E. Designing and Selecting Samples. In Qualitative Research Practice: A Guide for Social Science Students and Researchers; Ritchie, J., Lewis, J., Eds.; Sage: London, UK, 2003; pp. 77-108, ISBN 0-7619-7110-6.

74. Rasch, B.; Friese, M.; Hofmann, W.; Naumann, E. Verfahren für Nominaldaten. In Quantitative Methoden 2; Rasch, B., Friese, M., Hofmann, W., Naumann, E., Eds.; Springer: Berlin/Heidelberg, Germany, 2014; pp. 111-132, ISBN 978-3-662-43547-2.

75. Diaz-Bone, R. Statistik für Soziologen, 5th ed.; überarbeitete Auflage; UVK Verlag: München, Germany, 2019; ISBN 9783825252106.

76. Hammann, M.; Jördens, J. Offene Aufgaben codieren. In Methoden in der Naturwissenschaftsdidaktischen Forschung; Krüger, D., Parchmann, I., Schecker, H., Eds.; Springer: Berlin/Heidelberg, Germany, 2014; pp. 169-178, ISBN 978-3-642-37826-3.

77. Sellmann, D. Umweltbildung zum Thema Klimawandel im Botanischen Garten: Wissen, Einstellungen und Konzepte von Jugendlichen; Universität Bayreuth: Bayreuth, BY, USA, 2011.

78. Döring, N.; Bortz, J. Forschungsmethoden und Evaluation in den Sozial-und Humanwissenschaften, 5, Vollständig Überarbeitete, Aktualisierte und Erweiterte Auflage; Springer: Berlin/Heidelberg, Germany, 2016; ISBN 978-3642410888.

79. Greve, W.; Wentura, D.; Gräser, H.; Schmitz, U. Wissenschaftliche Beobachtung: Eine Einführung, 2nd ed.; Beltz: Weinheim, Germany, 1997; ISBN 3-621-27360-3.

80. Altman, D.G. Practical Statistics for medical Research, 1st ed.; Chapman and Hall: London, UK, 1991; ISBN 0-412-27630-5.

81. Cohen, J. Statistical Power Analysis for the Behavioral Sciences, 2nd ed.; Erlbaum: Hillsdale, NJ, USA, 1988; ISBN 0-8058-0283-5.

82. Gätje, C. Das sozio-ökonomische Monitoring im Nationalpark Schleswig-Holsteinisches Wattenmeer. In Besuchermonitoring und Ökonomische Effekte in Nationalen Naturlandschaften; Tagungsreihe: Naturschutz im Naturpark Thüringer Wald und im Biosphärenreservat Vessertal-Thüringer Wald, 2006; Biosphärenreservat Vessertal-Thüringer Wald: Schmiedefeld am Rennsteig, Germany, 2007; pp. 44-49.

83. Jefferson, R.L.; Bailey, I.; Laffoley, D.D.; Richards, J.P.; Attrill, M.J. Public perceptions of the UK marine environment. Mar. Policy 2014, 43, 327-337. [CrossRef]

84. Ankamah-Yeboah, I.; Xuan, B.B.; Hynes, S.; Armstrong, C.W. Public Perceptions of Deep-Sea Environment: Evidence from Scotland and Norway. Front. Mar. Sci. 2020, 7. [CrossRef]

85. Tonin, S.; Lucaroni, G. Understanding social knowledge, attitudes and perceptions towards marine biodiversity: The case of tegnùe in Italy. Ocean Coast. Manag. 2017, 140, 68-78. [CrossRef]

86. Sellmann, D. Environmental education on climate change in a botanical garden: Adolescents' knowledge, attitudes and conceptions. Environ. Educ. Res. 2014, 20, 286-287. [CrossRef] 
87. Gebhard, U. Zur Bedeutung von Naturerfahrungen für die seelische Entiwcklung, Wohlbefinden und Gesundheit. In Auf dem Weg zu Gutem Leben: Die Bedeutung der Natur für Seelische Gesundheit und Werteentwicklung; Jung, N., Molitor, H., Schilling, A., Eds.; Budrich UniPress Ltd.: Opladen, Germany; Budrich UniPress Ltd.: Berlin, Germany; Budrich UniPress Ltd.: Toronto, ON, Canada, 2012; pp. 31-42, ISBN 9783863880163.

88. Sellmann, D.; Bogner, F.X. Effects of a 1-day environmental education intervention on environmental attitudes and connectedness with nature. Eur. J. Psychol. Educ. 2013, 28, 1077-1086. [CrossRef]

89. Bexell, S.M.; Jarrett, O.S.; Ping, X. The Effects of a Summer Camp Program in China on Children's Knowledge, Attitudes, and Behaviors Toward Animals: A Model for Conservation Education. Visit. Stud. 2013, 16, 59-81. [CrossRef]

90. Aguirre-Bielschowsky, I.; Freeman, C.; Vass, E. Influences on children's environmental cognition: A comparative analysis of New Zealand and Mexico. Environ. Educ. Res. 2012, 18, 91-115. [CrossRef]

91. Wendel, W. Abneigung gegen Spinnen-Unterrichtsversuche zum Abbauen von Antipathien bei Schülern eines 7. Schuljahres. Biol. 1980, 16, 4-35.

92. Schanz, E. Zum Problem kindlicher Abneigung gegenüber Tieren- ein Beitrag zur Psychologie des Biologieunterrichtes. Biologieunterricht 1972, 8, 43-125.

93. Almahasheer, H.; Duarte, C.M. Perceptions of Marine Environmental Issues by Saudi Citizens. Front. Mar. Sci. 2020, 7. [CrossRef]

94. Gkargkavouzi, A.; Paraskevopoulos, S.; Matsiori, S. Public perceptions of the marine environment and behavioral intentions to preserve it: The case of three coastal cities in Greece. Mar. Policy 2020, 111, 103727. [CrossRef]

95. Uitto, A.; Juuti, K.; Lavonen, J.; Meisalo, V. Students' interest in biology and their out-of-school experiences. J. Biol. Educ. 2006, 40, 124-129. [CrossRef] 